\title{
ЕКОНОМІЧНА ПРОБЛЕМАТИКА \\ В УМОВАХ УКРАЇНСЬКОГО ДЕРЖАВОТВОРЕННЯ НА СТОРІНКАХ ЖУРНАЛУ «УНІВЕРСУМ» (1993-2018)
}

\author{
Вікторія Романчук \\ Всеукраїнський журнал політологї, футурологї, економіки, науки та культури \\ «ніверсум», а/с 2994, 79017, Львів, Украӥна \\ e-mail: viktoriya.romanchuk7@gmail.com \\ https://orcid.org/0000-0003-1594-3995
}

У статті проаналізовано публікації на економічну тематику в журналі «Універсум» упродовж 1993-2018 рр., які віддзеркалюють багатогранну й суперечливу картину ринкових реформ в Українській державі. Порушені авторами журналу економічні проблеми в Українській державі дозволяють краще зрозуміти причини вкрай повільного і далеко не задовілного процесу реформування суспільства на засадах ринкової економіки.

Key words: економіка, капітал, українська державність, ринковий фундаменталізм, ринкові реформи, глобалізація, російська експансія, науково-популярна література.

Вступ. Основною причиною краху економіки Української держави у 90-х роках минулого століття стала надзвичайно сильна інтеграція економіки УРСР в союзну. Перебуваючи тривалий час у тоталітарній системі, Україна була ізольована від міжнародного ринку. Рентабельність виробництва в СССР базувалась на трьох китах: дешева сировина, дешева робоча сила і жорстка охорона внутрішнього ринку державною монополією на зовнішню торгівлю. 2001 року академік НАНУ, доктор економічних і доктор технічних наук Михайло Павловський зазначив, що за роки так званих реформ Україна втратила понад 75\% свого економічного потенціалу, що майже вдвічі більше, ніж за роки Другої світової війни (40\%)․ Через непродумані й запізнілі реформи вільний ринок обернувся до нас звірячим обличчям дикого капіталізму, первісного накопичення капіталу, що, як відомо, в багатьох випадках здійснюється злочинним шляхом. На думку Михайла Павловського, «відсутність науково обгрунтованої програми реформ, бездумне впровадження «шокової терапії» МВФ і Світового Банку відтворили в Україні основні руйнівні чинники США 1929-1933 років - гіперінфляцію, кризу платежів, зниження якості робочої сили»². Крім того, влада Російської Федерації не повернула українську частину активів СССР (26 млрд

\footnotetext{
1 Павловський, Михайло (2001), «Вільний ринок без державного втручання в економіку - це шлях до економічного та політичного краху держави та нації», Універсум, Львів, № 11, с. 31.

2 Там само. С. 31.

(C) Романчук В., 2020
} 
доларів) законному власникові й Україна була змушена купувати російську нафту за ціною, яка в 4,5 рази перевищувала світову.

У 1991 році Україна мала найліпші можливості серед колишніх союзних республік СССР для виходу з економічної кризи. Однак здійнити це не вдалося через податкову систему - одну з найгірших у світі; через надзвичайно високий рівень корупції (журналісти Süddeutsche Zeitung у 2018 році дослідили, що Україна щороку втрачає через корупцію на митниці близько $€ 5$ мільярдів, що більше однієї десятої всієї дохідної частини бюджетуㄱ); через брак довіри у суспільстві - не вірять владі, не вірять банківській системі; через нерозуміння національних пріоритетів; через тіньову економіку; через брак національної стратегії розвитку; через постійне зменшення частки високотехнологічної продукції у структурі ВВП; через величезний зовнішній та внутрішній борг; через нерозуміння, що економіка $є$ складовою частиною культури; через недосконалу кадрову політику держави; через відсутність національного патріотичного проводу, коли політики на вищих щаблях влади неприховано толерують інші держави.

Займаючи $1 \%$ території земної кулі, Україна володіє 5,2\% світових запасів природних ресурсів, їй належать $40 \%$ європейських запасів чорноземів. Однак місце Української держави на економічній мапі світу нині майже непомітне - у 2018 році валовий внутрішній продукт (ВВП) Німеччини становив 4,0 трлн дол. США, в України - 131 млрд дол. ${ }^{4}$ в А Аргентини - 518,09 млрд дол. ${ }^{5}$ ВВП України - це 25 відсотків ВВП федеральної землі Баварія, кількість населення якої втричі менша, ніж в Україні

Публікації «Універсуму» на економічну тематику підтверджують давній класичний досвід: основою соціальних відносин у суспільстві є розподіл продуктів суспільної праці. Зараз у всьому світі спостерігається зрощення великого капіталу 3 владою. В Україні це явище набуло потворних рис і форм (досить згадати суперечку між Українською державою і одним з олігархів за контроль над націоналізованим Приватбанком), а в умовах російсько-українського протистояння може призвести до соціального вибуху, прискорення загальної дезорганізації суспільства. Отож треба вибрати один із трьох стратегічних шляхів здійснення економічних реформ: повернення до державного соціалізму, рух до ринкового фундаменталізму МВФ та Світового Банку, еволюційний курс у сім'ю розвинутих держав світу.

Для України саме третій шлях найприйнятніший, саме він $є$ шляхом удосконалення держави, досягнення нею успіху в сучасному глобалізованому світі. У цьому переконані автори «Універсуму».

\footnotetext{
3 SZ: «Корупція на митниці завдає Україні збитків у 5 мільярдів доларів на рік» (2018). URL: https://www.dw.com/uk/sz-корупція-на-митниці-завдає-україні-збитків-у-5-мільярдів-доларівна-рік/а-44963028

4 Яворський, Павло, Ніколаєва, Ольга, Шепотило, Олександр, Хорунжа, Марина, Таран, Світлана, Челмакіна, Крістіна (2019), «Як збільшити та диверсифікувати український експорт до Німеччини. Аналіз та рекомендації». URL: https://kse.ua/wp-content/uploads/2019/09/KSETrade Intesifying-UA-exports-to-Germany.pdf

5 Аргентина-Валовой внутренний продукт https://knoema.ru/atlas/Аргентина/ВВП

6 ВВП Украины - это 25\% от ВВП Баварии https://uainfo.org/blognews/1519984078-vvp-ukrainy-eto25-ot-vvp-bavarii.html
} 
Постановка проблеми. Спеціальні економічні видання адресовані упереваж науковцям і фахівцям. Йдеться насамперед про такі періодичні видання, як «Проблеми економіки», «Економіка і прогнозування», «Економіка України», «Економіка промисловості», «Економіст», «Економічна кібернетика», «Економічний аналіз», «Регіональна економіка», «Економіка розвитку» тощо.

За роки незалежності економічна думка Української держави збагатилась численими спеціальними дослідженнями дослідженнями на цю тему. Не лише в академічних колах здобули широку популярність праці відомих учених: С. Вовканичат, Б. Гаврилишина ${ }^{8}$, С. М. Злупка ${ }^{9}$ А. С. Гальчинського ${ }^{10}$, Ю. М. Пахомова ${ }^{11}$, М. А. Павловського ${ }^{12}$ та ін.

Разом з тим, у переломні моменти соціально-економічного розвитку країни роль економічної науки не просто зростає, а й потребує певного рівня популяризації - у суспільства з'являється потреба з'ясувати і зрозуміти проблеми, які безпосереднього стосуються громадян, їхньої вкрай важливої ролі у державному будівництві. Це й зрозуміло: економіка включає в себе не лише вузькофахові знання про закони розвитку господарської системи, але й суспільну етику, мораль, правову освіченість, еклогічну культуру, патріотизм у ставленні до рідної землі тощо.

Суспільству, яке прагне збудувати життя на демократичних засадах, вкрай потрібна економічна поінформованість. Треба мати впевненість, що на громадській базі постануть кращі перспективи життя і розвитку для задоволення соціальних потреб.

Слід відзначити, що економічна тематика в українській популярній періодиці практично відсутня. На проблему занепаду науково-популярної журналістики в українських мас-медіа звертає увагу Марина Варич ${ }^{13}$ та Олег Романчук ${ }^{14}$. Бракує, зокрема, популярного викладу основ економічної науки, що дозволяє громадянам краще усвідомити сутність і причини/витоки багатства і бідності, безробіття та ін-

Вовканич, С. (1999), Інформація, Інтелект, Нація, Львів, Євросвіт, 416 с.

8 Гаврилишин Б. (2009), До ефективних суспільств: Дороговкази в майбутнє: доп. Римському Клубові, Київ, Пульсари, 248 с.

9 Злупко, С. М. (2000), Економічна думка Украӥни, Львів, Львівський національний ун-т ім. Івана Франка, 495 с.; Злупко, С. М. уклад. (1998), Украӥнська економічна думка: хрестоматія, (1998), Київ, Знання, 447 с.

${ }^{10}$ Гальчинський, А. С. (2013), Нооекономіка, Київ, Либідь, 472 с.; Гальчинський, А. С. (1999), Україна: поступ у майбутне, Київ, Основи, 220 с.; Гальчинський, А. С. (1996), Кінець тоталітарного соиіалізму. Що далі?, Київ, Українські пропілеї, 160 с.; Гальчинський, А. С. (2011), Лібералізм. Уроки для України, Київ, Либідь, 288 с.; Гальчинський, А. С. (2009), Криза і ичикли світового розвитку, Київ, АДЕФ-Україна, 392 с.

${ }^{11}$ Пахомов, Ю. М., Крымский С. Б., Павленко Ю. В. (1998) Пути и перепутья соврменной циивилизаиии. Київ, Международный деловой центр, 432 с.

12 Павловський, М. (1996), Шлях Украӥни: Шлях вліво, илях вправо - хибний шлях, Київ, Техніка, 152 с.; Павловський, М. (1998), Ідеологія прогресивних реформ для України, Київ, Техніка, 56 с.; Павловський, М. (1997), Суспільство та економіка перехідного періоду, Київ, Техніка, 152 с.; Павловський, М. (2001), Стратегія розвитку суспільства: Україна і світ (економіка, політологія, соиіологія), Київ, Техніка, 312 с.; Павловський, М. (1999), Наш вибір. Відродження чи руйнація, Київ, Техніка, 48 с.

${ }^{13}$ Варич, Марина (2014), Науково-популярна журналістика як метод комунікації у соціокультурному просторі», Образ, Інститут журналістики КНУ імені Тараса Шевченка, вип. 15, с. 5-13.

${ }^{14}$ Романчук, Олег (2011), «Роль науково-популярної літератури у пропаганді знань», Вісник Львівського університету, сер. журн. вип. 34, с. 188-194. 
фляції, з’ясувати що таке бюджетний дефіцит і державний борг. Врахувавши згадані фактори впливу на загальносуспільні явища, можна прогнозувати розвиток подій, здійснювати заходи стимулювання або стримування, розвитку або гальмування, шукати ресурси для здійснення або зміни форми організації того чи іншого процесу.

3 огляду на такий стан речей (помітний брак матеріалів науково-популярного змісту на економічну тематику) редакція «Універсуму» значний обсяг свого видання приділяла саме популяризації економічних знань та роз'ясненню причин і витоків економічних проблеми сучасної України. Автори журналу в своїх публікаціях вдало поєднували популярність викладу з фаховим аналізом української та світової економіки.

Мету статті вбачаємо в тому, щоб з'ясувати основні напрями економічної тематики на сторінках не фахового наукового журналу впродовж 1993-2018 pp., звертаючи особливу увагу на ті шляхи виходу з кризи, яких пропонували дотримуватись автори «Універсуму».

Виклад матеріалу. Економічну проблематику на сторінках «Універсуму» докладно висвітлювали відомі вчені, фахівці, підприємці: академік НАНУ, доктор економічних і технічних наук Михайло Павловський, доктори економічних наук Степан Злупко, Веніамін Сікора, Степан Вовканич, Осип Мороз, Олег Соскін, Віктор Борщевський, Віктор Шевчук, Володимир Лановий, Іво Полулах, Юрій Саєнко. А також знані фахівці, які на прктиці добре орієнтуються в економічних процесах: президент Асоціації українських банків Олександр Сугоняко, президент АТ «Оболонь» Олександр Слободян, кандидат економічних наук Богдан Сікора, доктор фізико-математичних наук Леонід Шульман. Неодноразово виступав на сторінках «Універсуму» $\mathrm{i}$ член Римського Клубу, відомий у світі вчений-економіст українського походження Богдан Гаврилишин, який відіграв значну роль у залученні України до процесів глобальних трансформацій.

Чверть століття тому Володимир Кузьменко і Олег Романчук у статті «У полоні Надмонополії» ${ }^{15}$ докладно проаналізували недоліки та вади совєтської системи господарювання, через що всі галузі народного господарства СССР внаслідок технологічної відсталості стали нерентабельними.

Доктор економічних наук Степан Злупко знайомить читачів з матеріалами Першого конгресу Міжнародної української економічної асоціації, які містять чимало цікавих спостережень, думок і фактів в інтерпретації економістів-українознавців 3 різних країн світу ${ }^{16}$.

Директор Львівського відділення Інституту економічних досліджень Мар'ян Долішній в інтерв’ю «Універсумові» ${ }^{17}$ відзначає негативні наслідки трудової міграції: країну покидають найактивніші висококваліфіковані працівники. Прогнози відомого економіста невтішні: становище, в якому опинилась українська економіка вимагає вжиття найрішучіших організаційних і економічних заходів з боку владних структур, слід більш ефективно задіяти мотиваційні механізми - стимулюючі й штрафрні санкції аби зупинити хаос у народному господарстві.

\footnotetext{
${ }^{15}$ Кузьменко, Володимир і Романчук, Олег (1994) «У полоні Надмонополії», Універсум, Львів, № 1-2, c. 14-15.

16 Злупко, Степан (1994), «Економіка України: минуле, сучасне і майбутнє», Універсум, Львів, № $7-8$, c. 27.

17 Долішній, Мар'ян (1994), «На пра..., на лі..., кругом!», Універсум, № 7-8, с. 28-29.
} 
Президент Української світової кооперативної ради (США) Дмитро Григорчук переконливо обгрунтовує гасло «Українська кооперація - це міцна родина і міцна спільнота! $»^{18}$. Він зазначає, що відродження доброго імені української кооперації насамперед в руках її лідерів: «Доля кооперації залежить від того, наскільки швидко громадяни України переконаються в доцільності розвитку організацій дрібного кредиту, виробницьва і торгівлі».

Доктор економічних наук Степан Злупко застерігає $\epsilon^{19}$, що недооцінка досвіду минулого може мати трагічні наслідки для української економіки, яка нині вибирається на шлях загальноцивілізаційного поступу. Вчений звертає увагу на те, що у моделі національної економіки $є$ вразливі місця, зокрема йдеться про надання переваг у зовнішньоекономічній діяльності проросійській орієнтації.

Володимир Шевчук, доктор економічних наук, пише ${ }^{20}$ про нагальну потребу оновлення економічних знань в новітніх умовах суспільно-господарського розвитку, про певний «симбіоз» у співвідношенні між державними та ринковими регуляторами. Учений аргументує конечну потребу опанування економічно й соціально орієнтованими знаннями для побудови новітньої моделі господарювання.

Доктор економічних наук Іван Михасюк переконаний, що справжнього суверенітету держави можна досягти через ефективну економічну політику, орієнтовану на створення конкурентоспроможної соціально орієнтованої економіки ${ }^{21}$.

Голова Державного комітету зі стандартизації, метрології та сертифікації Тетяна Кисільова стурбована, що європейське співтовариство не поспішає бачити Україну як рівноправноого торгового партнера, натомість хоче зберегти широкий доступ товарів $€ С$ на український ринок 22.

Михайло Романюк, кандидат економічних наук, звертає увагу на конечну потребу розробки міграційної політики для оптимізації міграційних процесів в Українській державі, враховуючи значні обсяги зовнішніх переміщень громадян через іiі кордон ${ }^{23}$.

У статті «Чи вирветься Україна із зашморгу міжнародних фінансистів?» ${ }^{24}$ доктор фізико-математичних наук Леонід Шульман з'ясовує, чи $є$ благом для економіки України західні кредити, Міжнародний валютний фонд, що ховається за термінами «глобалізація», «інвестиції», «лібералізація», «приватизація» тощо. Прискіпливо проаналізувавши «Меморандум економічної політики на період з 1 липня 1998 року по 30 червня 2001 року» автор приходить до висновку, що Україна перетворилась на «фінансового наркомана», узалежненого від ліберальних «фінансових махінаторів»,

${ }_{18}$ Григорчук, Дмитро (1995), «Кредитні кооперативи - до добра і краси», Універсум, Львів, № 9-10, c. 24-26.

19 Злупко, Степан (1995), «Минуле, сучасне і майбутнє української економіки», Універсум, Львів, № 11-12, с. 17-19.

${ }^{20}$ Шевчук, Володимир (1996), «Новітня парадигма економічних знань», Універсум, Львів, № 3-4, c. $42-44$; № 7-8, c. $22-23$.

${ }^{21}$ Михасюк, Іван (1996), «Економічна політика України», Універсум, Львів, № 7-8, с. 24-26.

${ }^{22}$ Кисільова, Тетяна (1997), «Кому вигідна дорога з одностороннім рухом?», Універсум, Львів, № 9-10, с. 14-15.

${ }^{23}$ Романюк, Михайло (1998), «Регулювання міграцій - вимога сьогодення», Універсум, Львів, № 7-8, с. 26-30.

${ }^{24}$ Шульман, Леонід (1999), «Чи вирветься Україна із зашморгу міжнародних фінансистів?», Універсум, Львів, № 5-6, с. 18-22. 
уподібнилась державі, проти населення якої здійснюється економічно обгрунтований геноцид. Учений занепокоєний тим, що «від імені народу уряд та Нацбанк взяли зобов'язання знищити власне виробництво, науку, освіту, охорону здоров'я».

У своїй наступній статті «Шлях деградації нації та держави - ліберально-монетаристське реформування економіки» ${ }^{25}$ Леонід Шульман переконливо показує антиринковий характер сучасних економічних реформ в Україні, пропонує альтернативний шлях й називає технології зміни напрямку економічних реформ.

Академік НАНУ, доктор технічних та економічних наук, народний депутат України Михайло Павловський у статті «Світ і Україна на порозі третього тисячоліття: шляхи розвитку» ${ }^{26}$ розмірковує про шляхи розвитку України на порозі третього тисячоліття: «За 8 років реформ Україна втратила понад 74\% свого економічного потенціалу (зазначимо, що за 4 роки Другої світової війни Україна втратила близько $40 \%$ економічного потенціалу), завершила деіндустріалізацію країни, майже повністю знищивши 8 промислових галузей (легка промисловість скоротилась у 8 разів, електронна промисловість більш ніж в 100 разів тощо). <...> Відбулось це через антинауковий характер та помилки з погляду економічної науки тих рекомендацій та вимог, які давали і ставили Президенту і Уряду іноземні радники-консультанти і які відображались в меморандумах між Урядом України та МВФ. <...> Захід ніколи не проводив у себе реформи за моделлю МВФ. Це рецепт Заходу для слаборозвинутих країн. Всі ті країни, які досягли успіхів в економічному розвитку, ніколи не співпрацювали із МВФ».

Економічну проблематику на сторінках «Універсуму» порушував і перший Президент України Леонід Кравчук ${ }^{27}$. Він ділиться своїми думками щодо майбутнього державного і національного становища України в глобальній економіці. Леонід Кравчук наголошує, що «відмова від наукових, особливо фундаментальних досліджень (посилаючись на вкрай складні економічні умови), або різке, в кілька разів, скорочення їх кількості, призведе до трагічних наслідків. У сучасній науці надолужити прогаяне дуже важко. Якщо ми відстанемо від високорозвинених країн (а без фундаментальних досліджень це неминуче), знадобляться десятиріччя, аби наздогнати їх».

Михайло Павловський в іншій своїй статті «Стійкість економічної системи необхідна умова зростання добробуту $2^{28}$ аналізує економічні проблеми, які постали перед світом і Україною на порозі XXI століття. Учений, зокрема, звертає увагу на те, що економічні реформи як перехід від соціалізму до ринкових відносин у другій половині XX століття проводилися за єдиною моделлю Чиказької неоконсервативної школи на базі монетаристської теорії Фрідмена, яку впроваджували в життя Міжнародний валютний фонд (МВФ) і Світовий банк (СБ) як в латиноамериканських, так і в постсоціалістичних країнах, незважаючи на їх абсолютно різні стартові умови як за географічним положенням, природними ресурсами, менталітетом, так і за

\footnotetext{
${ }^{25}$ Шульман, Леонід (1999), «Шлях деградації нації та держави - ліберально-монетаристське реформування економіки», Універсум, Львів, № 9-10, с. 27-31, 37-41.

26 Павловський, Михайло (2000), «Світ і Україна на порозі третього тисячоліття: шляхи розвитку», Універсум, Львів, № 1-2, с. 12-15.

${ }^{27}$ Кравчук, Леонід (2000), «Погляд у ХХІ століття», Універсум, Львів, № 7-10, с. 6-11.

${ }^{28}$ Павловський, Михайло (2001), «Стійкість економічної системи - необхідна умова зростання добробуту», Універсум, Львів, № 1-2, с. 11-16.
} 
науково-технічним і освітнім рівнем народів. Реформи за цією моделлю, на думку академіка, виявились надзвичайно затратними і руйнівними. Михайло Павловський застерігає: «Для того, щоб ввести Україну в коло технологічно розвинутих держав, треба змінити курс від псевдореформ саморуйнування, самоліквідації та деградації суспільства, які закладені в моделі ринкового фундаменталізму, нав’язаній МВФ та СБ < ..> Головною небезпекою, загрозою, перепоною для реалізації в Україні прогресивного курсу реформ із входженням в коло технологічно розвинутих держав $\epsilon$ кримінальні олігархи, що відстоюють деградативний курс реформ на основі ринкового фундаменталізму».

Не втратив актуальності висновок уже цитованого Михайла Павловського в його інтерв” «Універсуму» 2001 року: «Реформи проводяться тоді, коли виявляється низька ефетивність економічної системи, виникають економічні кризи, економіки недостатньо задовольняє потреби людей, країна відстає в своєму розвитку від інших країн $\rangle^{29}$.

Доктор економічних наук, професор Національної Академії управління Веніамін Сікора глибоко аналізує уроки першої спроби Української держави вирватися 3 лещат відсталого регресивного різновиду капіталізму ${ }^{30}$. Він пише: «У 1992 році планова економіка в Україні зазнала демонтажу. Відтоді до 1999 року руйнування, розпад старої економіки супроводжується будівництвом переважно перекручених форм ефективної ринкової економіки. Інакше кажучи, відбувалось утвердження відсталого капіталізму, причому темпами, значно швидшими, ніж виникали елементи, паростки здорового, справедливого, ефективного ринкового типу економіки. <...> Суть проблеми полягає в тому, що < ..> більшість фінансових ресурсів українських олігархів (25-30 мільярдів доларів) знаходиться за кордоном на рахунках у західних банках або в таємних сховищах світової офшорної фінансової системи». Учений звертає увагу на обтяжливу обставину - розлад і безладдя в культурному середовищі Україні, що несумісно з існуванням ринкової економіки.

На сторінках «Універсуму» неодноразово лунали застереження щодо небезпеки російської економічної експансії в Україні. Цій проблемі присвятив свою статтю «Російська економічна експансія в Україні»»13 заступник директора Центру прогнозування соціально-економічних та політичних процесів Богдан Сікора. Історія підтвердила слушність застережень ученого. 3 огляду на конечну важливість порушеної теми в умовах гібридрної війни, яку Росія веде проти України, доцільно зацитуати деякі фрагменти статті: «Якщо в першій половині 90-х років Росія не володіла жодним українським металургійним заводом, то в 2001 р. в Україні вже склався потужний сектор російських металургійних підприємств, що виробляють левову частку української металургійної продукції. < ..> У 2001 році Росія вже контролювала головні промислові підприємства Західної України. Російський капітал в 2001 р., за оцінками експертів, поширився на шість галузей української економіки.<...> Росія може контролювати роботу підприємств України, справляючи вплив на політичну,

29 Павловський, Михайло (2001), «Вільний ринок без державного втручання в економіку - шлях до економічного і політичного краху держави і нації,, Універсум, Львів, № 11-12, с. 33.

${ }^{30}$ Сікора, Веніамін (2001), «Україна: від капіталізму до капіталізму», Універсум, Львів, № 5-6, c. $15-19$.

${ }^{31}$ Сікора, Богдан (2002), «Російська економічна експансія в Україні», Універсум, Львів, № 7-8, 2002, c. 28-30. 
економічну, громадську, інформаційну сфери. Російський капітал може безпосередньо і опосередковано впливати на: роботу парламентських фракцій; діяльність політичних партій; неформальні громадсько-політичні угруповання (земляцтва, клани, родинні об'єднання, групи за інтересами); функціонування державного силового відомства, державного галузевого міністерства (комітету); інституціоналізовані та неформальні об'єднання підприємців; громадські об'єднання неполітичного призначення; компанії, що є конкурентами підприємства, на яке хоче вплинути Росія».

Богдан Сікора перелічує конкретні негативні наслідки російської економічної експансії в Україні: посилення культурної русифікації українського населення; посилення впливу проросійських сил в Україні; перехід від «двовекторної» до одновекторної - проросійської зовнішньополітичної орієнтації України; перетворення України на економічну колонію Росії; створення економічних передумов для входження України до Союзу Росії та Білорусі; дискредитація проєвропейського, прозахідного політичного курсу України; наслідування Україною економічно відсталої кримінально-корупційної моделі російської економіки; ще більше посилення економічної залежності України від Росії; завдання збитків національній безпеці України.

Автор акцентує на основних напрямах використання доходів російських компаній. Насамперед йдеться про фінансування: виборчих кампаній політиків та політичних сил, що дотримуються проросійської орієнтації; проектів культурної та інформаційної русифікації України; придбання або взяття під контроль Росії мас-медіа, що діють в Україні; проектів збереження економічної, торговельної та зовнішньоекономічної залежності України від Росії; мережі російських агентів впливу, що діє в Україні; регіонального сепаратизму всередині України; корумпованих політичних сил України, що дотримуються проросійської орієнтації.

Михайло Павловський і голова правління науково-технічного впровадницького підприємства «Агро» (м. Івано-Франківськ) Богдан Головенко у дослідженні «Глобалізація і національна стратегія України у XXI столітті» ${ }^{32}$ застрегають, що нав'язане Украні ззовні й виконуване ії державними лідерами будівництво капіталізму може відкинути країну до межі, коли результати такого будівництва матимуть невиправний, незворотний характер. Автори наголошують, що нашим державним лідерам слід зрозуміти різницю між капіталізмом і ринковою економікою.

Привертає увагу науково-політологічною та економічною переконливістю розлогий аналіз сучасної ринкової економіки в Україні доктора фізико-математичних

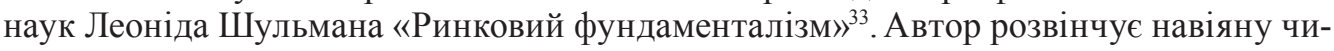
тачеві, слухачеві чи глядачеві спрощену думку, «нібито існують лише два альтернативних типи економіки: хороша ринкова і погана планова». Учений наголошує: «План - це спосіб організації виробництва. Ринок - це механізм розподілу валового внутрішнього продукту (ВВП) серед членів суспільства. Безпланове виробництво неможливе взагалі. Не було й немає країни, де б існував, наприклад, тільки вільноринковий розподіл». Учений розкриває небезпеки, які приховує ринковий фундаменталізм: «Реформи на фундаменталістських засадах повсюдно мали лише негативні наслідки - повну руйнацію економік країн, які пішли цим шляхом. Економічні кризи

\footnotetext{
32 Павловський, Михайло і Головенко, Богдан (2002), «Глобалізація і національна стратегія України у ХХІ столітті», Універсум, Львів, № 9-10, с. 35-40.

${ }_{33}$ Шульман, Леонід (2002), «Ринковий фундаменталізм», Універсум, Львів, № 11-12, с. 13-16.
} 
неодноразово уражали Мексику, Аргентину, Бразилію, Перу та інші аналогічні країни. Розвинені ж держави Свропи та Північної Америки розвивалися природнім шляхом, де ринковому фундаменталізму місця не знайшлося. Розвинені нові індустріальні країни Азії (Японія, Південна Корея, Тайвань, а зараз і Китай) взагалі йшли діаметрально протилежним шляхом: замість лібералізації та дерегуляції - розвиток економіки під керівництвом і за сприяння держави (те, що називають дирижизмом). Типово дирижистськими діями були Новий курс президента Рузвельта, що вивів США із кризи 1929-1930 pp., а також політика французького президента Шарля де Голля».

Лідія Мельник, заступник директора Департаменту співробітництва з СОТ Міністерства економіки та 3 питань європейської інтеграції України, переконана, що вступ України до СОТ забезпечить умови для збільшення іноземних інвестицій в економіку України та загального економічного зростання, забезпечить участь у регіональних союзах та угрупованнях, забезпечить лібералізацію доступу українських товарів на ринки світу, гарантуватиме визнання за Україною в антидемпінгових розслідуваннях статусу ринкової економіки, дозволить запобігти загрозі торговельно-економічної ізоляції не тільки від країн Західної та Центральної Європи, а й від країн Східної Європи та Балтії, багато з яких вже сьогодні $є$ асоційованими членами $\mathrm{\epsilon C}$, забезпечить ширший вибір товарів і послуг для споживачів ${ }^{34}$.

Доктор економічних наук Юрій Жук відзначає, що тодішня українська влада не звернулася до Росії з вимогою, як це зробили Литва, Латвія та Естонія, повернути частину активів СССР у розмірі 26 млрд. доларів, якими Москва безоплатно користується, за що повинна була б, по-чесному, виплатити Україні понад 50 млрд. доларів 3 розрахунку $10 \%$ річних $^{35}$. Вчений наголошує, що ми в цей час платили за російську нафту в 4,5 раза дорожче від світової ціни.

Леонід Шульман звертає увагу на те, що в українській владі чимало ринкових фундаменталістів, реформацію на засадах ринкового фундаменталізму підтримує і частина нашої гуманітарної інтелігенції ${ }^{36}$. Учений перелічує найбільш загрожені ділянки національного буття через реформацію економіки на засадах ринкового фундаменталізму: економічна безпека, оскільки сприяє перетворенню країни на споживача кінцевого продукту розвинених країн та постачальника на світовий ринок дешевої сировини; продовольча безпека, оскільки усуває державу від стабілізації ринку зерна та продовольства взагалі; фінансова безпека; обороноздатність; інтелектуальний потенціал; інформаційна безпека; національна культура. Автор слушно зауважує, що на економічній шахівниці грає не двоє, а троє гравців: нація, держава та бізнес (капітал). На думку вченого, ринковий фундаменталізм - ідеологічне й пропагандистське прикриття інтересів капіталу.

Доктор економічних наук Сергій Борщевський у статті «Ліберальна модель економічного розвитку України» ${ }^{37}$ звертає увагу на неефективне використання держав-

${ }_{34}$ Мельник, Лідія (2003), «Можливості для українських підприємств після вступу до СОТ та створення зони вільної торгівлі з СС», Універсум, Львів, № 11-12, с. 25-27.

35 Жук, Юрій (2004), «Україна: час втрачених можливостей», Універсум, Львів, № 7-9, с. 5-8.

${ }^{36}$ Шульман, Леонід (2005), «Ринковий фундаменталізм - загроза національній безпеці», Універсум, Львів, № 1-4, с. 14-22.

37 Борщевський, Сергій (2007), «Ліберальна модель економічного розвитку України», Універсум, Львів, № 3-4, с. 5-10. 
ного бюджету. На його думку, треба абстрагуватися від вторинних суспільно-політичних проблем і насамперед сконцентрувати увагу на визначенні фундаментальних пріоритетів економічного розвитку держави, пов'язавши їх з відповідною системою моральних цінностей.

У статті «Українська криза: чи перезавантажиться «матриця»?» ${ }^{38}$ Сергій Борщевський продовжує аналізувати стан української економіки: «У нашій державі, де влада тривалий час ігнорувала структурну розбалансованість економіки, рівень розуміння механізмів поширення та витоків кризи залишається, у кращому разі, на рівні Марксового «Капіталу»...Проте, на відміну від Маркса, передбачається забирати в бідних і віддавати багатим, які під час кризи, начебто, постраждали найбільше. $<\ldots>$ Все це до болю нагадує совєтську дійсність. Те ж нестримне бажання виграти у держави в заздалегідь програшну «лоторею», те ж прагнення влади захищати ледацюг та нероб за рахунок працьовитої частини населення».

Доцент кафедри економічної теорії Львівського державного аграрного університету Василь Здоровик у статті «Інфляція в Україні» ${ }^{39}$ веде мову про позитивні й негативні сторони інфляції, котра так чи інакше зачіпає інтереси держави, підприємців, усіх громадян. Автор звертає увагу на те, що інфляція має бути прогнозованою і регульованою. Якщо інфляція виходить за межі 10 відсотків, то процес фінансово-кредитного регулювання економіки значно ускладнюється.

У статті «Фінансово-економічна криза: ㄲï причини та наслідки» ${ }^{40}$ Василь Здоровик відзначає, що за роки незалежності в Україні не створена сучасна промисловість, яка продукує досконалі засоби виробництва і предмети особистого вжитку (одяг, взуття, побутову техніку тощо). «Ринок насичений імпортними товарами, економіка енергозатратна. На одиницю валового внутрішнього продукту в Україні витрачається у десятки разів більше енергетичних ресурсів (передусім газу), ніж у розвинених країнах. Сформувалась віртуальна економіка, віртуальний бюджет, віртуальні доходи населення і фірм, віртуальний достаток».

Професор Українського Вільного Університету в Мюнхені доктор Іво Полулях переконаний, що соціальне ринкове господарство як синтез економічної виробничої діяльності та творчих факторів у соціально- політичному секторі є третім шляхом між екстремальною формою приватного капіталізму та державного капіталізму комуністичного типу ${ }^{41}$. Разом 3 тим учений вважає, що «основою соціального ринкового ладу є право на приватну власність, воно є складовою частиною соціального ладу». На його думку, соціальна ринкова економіка об’єднує гарантовані законом свободи з вимогами соціальної безпеки та соціальної справедливості.

Професор Львівської комерційної академії доктор економічних наук Віктор Шевчук у статті «Газове питання: у пошуках справедливої ціни» ${ }^{42}$ доходить висновку: «Справедливої ціни на російський газ можна досягти лише за умови, що Україна

\footnotetext{
${ }^{38}$ Борщевський, Сергій (2009), «Українська криза: чи перезавантажиться «матриця»?», Універсум, Львів, № 1-2, с. 7-10.

39 Здоровик, Василь (2008), «Інфляція в Україні», Універсум, Львів, № 3-4, с. 16-19.

40 Здоровик, Василь (2009), «Фінансово-економічна криза: їі причини та наслідки», Універсум, Львів, № 1-2, с. 5-6.

${ }^{41}$ Полулях, Іво (2012), «Економічна політика», Універсум, Львів, № 3-4, с. 28-30.

${ }^{42}$ Шевчук, Віктор (2012), «Газове питання: у пошуках справедливої ціни», Універсум, Львів, № 5-6, c. 21-24.
} 
матиме таку саму переговорну силу, що й Німеччина, а для цього потрібні не гострі слова і не солодкі запевнення у вічному «братерстві», а послідовні кроки щодо зменшення споживання природного газу та диверсифікації джерел його постачання».

Володимир Вітковський у статті «Деіндустріалізація: національне самогубство по-українськи» ${ }^{43}$ наводить повчальні приклади функціонування економіки в так званих країнах «третього світу», порівнює їхню економіку з українською. Його спостереження суголосні з висновками фахівців, які наголошують, що саме розвинений сектор матеріального виробництва $є$ унікальним поживним середовищем для зростання середнього класу, відтак становить основу будь-якої національної демократії. Автор пише: «Дотепер чимало українців сприймає Мексику як країну «третього світу» $<\ldots>$ Але порівняймо факти. В 2013-му душовий ВВП становив, відповідно, \$10.307 в Мексиці й \$3.900 в Україні. <..> Між 1991 і 2003 роками сталося чотириразове (!) збільшення мексиканської зовнішньої торгівлі. Країна обігнала США за випуском інженерів з дипломами міжнародного зразка, разом з тим вартість розробок і виробництва залишається відносно низькою. Років тридцять тому мексиканська електроніка перебувала приблизно в такому ж стані, як вирощування цитрусових в Україні $<\ldots>$ Сьогодні 30\% мексиканського експорту становлять вироби електронної промисловості. На підйомі перебуває аерокосмічна галузь, зокрема гелікоптеро- та двигунобудування. Найпотужніші в світі нафтохімічні комбінати теж «прописані» на мексиканській землі. Країна $є$ третьою світовою потугою з виробництва цементу, батьківщиною найбільших операторів на ринках харчових продуктів та алкогольних напоїв. До слова, Мексика продукує також значну кількість високотехнологічного озброєння, і при тому не $є$ членом жодних проросійських політичних угруповань $<\ldots>$ Індустріальний злет країни ацтеків $\epsilon$ наочним прикладом того, чим могла б стати незалежна Україна (при цьому з набагато меншими зусиллями), якби не пофігізм іiї еліт i, треба визнати, значної частини інтелектуалів та середнього класу».

Президент Центру ринкових реформ, доктор економічних наук Володимир Лановий вважає, що Україні слід приєднатися до економічних санкцій західних країн щодо Росії. Йдеться про закриття внутрішніх ринків од російських поставок і припинення кредитування банкам агресора. Бо й справді історії невідомі випадки, коли б війна між країнами супроводжувалася вільним економічним обміном між ними. Автор пояснює. Автора дивує, чому в Україні триває дискусія щодо торговельних відносин з окупованим Донбасом ${ }^{44}$.

Ерік Райнерт, один із кращих європейських економістів, який доклав руку до успіхів Перу й Малайзії, у розмові з Ольгою Духнич стверджує, що вільний ринок перетворить Україну на великого аграрія та країну емігрантів, і пояснює, як цього уникнути ${ }^{45}$. «Поки ви неуспішні, - зазначає економіст, - у вас купуватимуть, але щойно ви станете успішними і виникне загроза, що ви порушите внутрішній ринок європейських країн, це може припинитися». На думку Райнерта, Україні потрібна не гуманітарна допомога, а дешевий капітал для відновлення промисловості.

43 Вітковський, Володимир (2015), «Деіндустріалізація: національне самогубство по-українськи», Універсум, Львів, № 3-4, с. 35-37; № 5-6, с. 24-26.

44 Лановий, Володимир (2015), «Економіка безглуздої війни», Універсум, Львів, № 7-8, с. 31-34.

45 Райнерт, Ерік (2015), «Вільний ринок перетворить Україну на країну емігрантів», Універсум, Львів, № 11-12, с. 40. 
Український підприємець, викладач Києво-Могилянської бізнес-школи Валерій Пекар розповідає про міграційну проблему в Україні та перепис населення, про бізнес-клімат та інвестиції, а також про ринок землі й те, що потрібно для підвищення зарплат у країні. Він пише: «Ми звикли вважати, що ми дурні - бо бідні, а бідні - бо дурні. Хоча це абсолютно неправда. Ми дуже розумна нація, подивіться на всі рейтинги людського капіталу, талантів тощо. У них Україна посідає десь 331 до 41 місця. Тепер питання: чому ми тоді такі бідні? Тому що ми свій марафон біжимо в кайданках на руках і ногах й добігаємо 150-ми в світі. Зняти кайданки дуже просто: потрібно мати політичну волю» ${ }^{46}$.

Голова Ради Незалежної асоціації банків України Роман Шпек аналізує реальні економічні ризики, які очікують Україну без отримання коштів від МВФ і як це відобразиться на добробуті громадян. Він переконаний, що накопичених валютних ресурсів замало, аби безболісно пройти 2019 та 2020 роки. На його думку, якщо таке скорочення золотовалютних резервів триватиме, то фінансові ринки зірвуться у неконтрольоване піке, а кредити стануть недоступними для бізнесу і населення ${ }^{47}$.

Висновки. Досліджуючи матеріали часопису, оприлюднені в рубриці «Економіка» впродовж 1993-2018 рр., можемо стверджувати, що публікації «Універсуму» загалом об’єктивно віддзеркалювали економічний розвиток України, максимально точно відображаючи найвиразніші й найбільш значущі моменти та обставини державотворення. Думки авторів «Універсуму», як правило, націлені у майбутнє. У своїх статтях вони вказували на шляхи удосконалення держави, порушували питання будівництва ефективної структури управління країною в усіх ділянках господарства, постійно наголошуючи, що майбутне нашої держави у нових технологіях, високорентабельному аграрно-промисловому комплексі, що вкрай важливе для України - високоякісна продукція.

Публікації журналу неодноразово звертали увагу на проблеми вільного ринку; на серйозні перешкоди розвиткові країни через скорочення іï трудового потенціалу; на численні негативні наслідки російської економічної експансії в різні галузі української промисловості, зокрема металургійної, нафтової та газової, що у висліді дозволяє не лише контролювати роботу підприємств України, а й впливати на політичну, економічну, громадську, інформаційну сфери; на загрози національній безпеці в результаті захоплення російським капіталом українського медіаринку; на перешкоди для інвестиційного клімату України внаслідок її неприєднання до економічних санкцій західних країн проти агресора в умовах відкритої гібридної війни Росії проти нашої держави; про нагальну потребу для України дешевого капіталу для відновлення промисловості тощо.

Редакційна колегія видання ретельно добирала фахових авторів, яким притаманне концептуальне і конструктивне мислення: С. Борщевський, С. Вовканич, Б. Гаврилишин, А. Гальчинський, М. Долішній, С. Злупко, В. Лановий, М. Павловський, І. Полулях, Ю. Саєнко, В. Черняк, В. Шевчук, Л. Шульман та ін.

\footnotetext{
${ }^{46}$ Пекар, Валерій (2018), «Ситуація з економікою жахлива, все можуть змінити кілька простих речей», Універсум, Львів, № 5-6, с. 37-39.

${ }^{47}$ Шпек, Роман (2018), «Транш МВФ - питання життя чи дефолту для України», Універсум, Львів, № 9-10, c. 37 .
} 
За складністю економічної проблематики, за рівнем аргументації публікації «Універсуму» не поступаються фаховим виданням, але водночас ці тексти - популярні й доступні для широкого кола читачів.

\section{СПИСОК ЛІТЕРАТУРИ}

1. Аргентина - Валовой внутренний продукт. URL: https://knoema.ru/atlas/Aргенти$\underline{\text { на/ВBП }}$

2. Борщевський, Сергій (2007), «Ліберальна модель економічного розвитку України», Універсум, Львів, № 3-4, с. 5-10.

3. Борщевський, Сергій (2009), «Українська криза: чи перезавантажиться «матриця»?», Універсум, Львів, № 1-2, с. 7-10.

4. Варич, Марина (2014), Науково-популярна журналістика як метод комунікації у соціокультурному просторі», Образ, Інститут журналістики КНУ імені Тараса Шевченка, вип. 15, с. 5-13.

5. ВВП Украины - это 25\% от ВВП Баварии. URL: https://uainfo.org/ blognews/1519984078-vvp-ukrainy-eto-25-ot-vvp-bavarii.html

6. Вітковський, Володимир (2015), «Деіндустріалізація: національне самогубство по-українськи», Універсум, Львів, № 3-4, с. 35-37; № 5-6, с. 24-26.

7. Вовканич, С. (1999), Інформація, Інтелект, Нація, Львів, Свросвіт, 416 с.

8. Гаврилишин Б. (2009), До ефективних суспільств: Дороговкази в майбутнє: доп. Римському Клубові, Київ, Пульсари, 248 с.

9. Гальчинський, А. С. (2013), Нооекономіка, Київ, Либідь, 472 с.

10. Гальчинський, А. С. (1999), Украӥна: поступ у майбутнє, Київ, Основи, 220 с.

11. Гальчинський, А. С. (1996), Кінецьь тоталітарного соціалізму. Що далі?, Київ, Українські пропілеї, 160 с.

12. Гальчинський, А. С. (2011), Лібералізм. Уроки для України, Київ, Либідь, 288 с.

13. Гальчинський, А. С. (2009), Криза і ичикли світового розвитку, Київ, АДЕФ-Україна, 392 с.

14. Григорчук, Дмитро (1995), «Кредитні кооперативи - до добра і краси», Універсум, Львів, № 9-10, с. 24-26.

15. Долішній, Мар’ян (1994), «На пра..., на лі..., кругом!», Універсум, № 7-8, с. 28-29.

16. Жук, Юрій (2004), «Україна: час втрачених можливостей», Універсум, Львів, № $7-9$, c. $5-8$.

17. Здоровик, Василь (2008), «Інфляція в Україні», Універсум, Львів, № 3-4, с. 16-19.

18. Здоровик, Василь (2009), «Фінансово-економічна криза: її причини та наслідки», Універсум, Львів, № 1-2, с. 5-6.

19. Злупко, С. М. (2000), Економічна думка Украӥни, Львів, Львівський національний ун-т ім. Івана Франка, 495 с.

20.Злупко, С. М. уклад. (1998), Українська економічна думка: хрестоматія, Київ, Знання, 447 с.

21. Злупко, Степан (1994), «Економіка України: минуле, сучасне і майбутнє», Універсум, Львів, № 7-8, с. 27.

22.3лупко, Степан (1995), «Минуле, сучасне і майбутнє української економіки», Універсум, Львів, № 11-12, с. 17-19. 
23. Кисільова, Тетяна (1997), «Кому вигідна дорога з одностороннім рухом?», Універсум, Львів, № 9-10, с. 14-15.

24. «Корупція на митниці завдає Україні збитків у 5 мільярдів доларів на рік» (2018). URL: https://www.dw.com/uk/sz-корупція-на-митниці-завдає-україні-збитків-у-5-мільярдів-доларів-на-рік/а-44963028

25. Кравчук, Леонід (2000), «Погляд у ХХІ століття», Універсум, Львів, № 7-10, с. 6-11.

26. Кузьменко, Володимир і Романчук, Олег (1994) «У полоні Надмонополії», Універсум, Львів, № 1-2, с. 14-15.

27. Лановий, Володимир (2015), «Економіка безглуздої війни», Універсум, Львів, № 7-8, с. 31-34.

28. Мельник, Лідія (2003), «Можливості для українських підприємств після вступу до СОТ та створення зони вільної торгівлі з СС», Універсум, Львів, № 11-12, c. $25-27$.

29. Михасюк, Іван (1996), «Економічна політика України», Універсум, Львів, № 7-8, c. 24-26.

30. Павловський, Михайло (2001), «Вільний ринок без державного втручання в економіку - це шлях до економічного та політичного краху держави та нації», Універсум, Львів, № 11, с. 31. URL: http://www.universum.lviv.ua/magazines/universum/2001/5/pavl.html

31. Павловський, М. (1996), Шлях України: Шлях вліво, шлях вправо - хибний шлях, Київ, Техніка, 152 с.

32. Павловський, М. (1998), Ідеологія прогресивних реформ для Украӥни, Київ, Техніка, 56 с.

33. Павловський, М. (1999), Наш вибір. Відродження чи руйнація, Київ, Техніка, 48 с.

34. Павловський, М. (1997), Суспільство та економіка перехідного періоду, Київ, Техніка, 152 с.

35. Павловський, М. (2001), Стратегія розвитку суспільства: Украӥна і світ (економіка, політологія, соціологія), Київ, Техніка, 312 с.

36. Павловський, Михайло (2000), «Світ і Україна на порозі третього тисячоліття: шляхи розвитку», Універсум, Львів, № 1-2, с. 12-15.

37. Павловський, Михайло (2001), «Стійкість економічної системи - необхідна умова зростання добробуту», Універсум, Львів, № 1-2, с. 11-16.

38. Павловський, Михайло (2001), «Вільний ринок без державного втручання в економіку - шлях до економічного і політичного краху держави і нації», Універсум, Львів, № 11-12, с. 33.

39. Павловський, Михайло і Головенко, Богдан (2002), «Глобалізація і національна стратегія України у XXI столітті», Універсум, Львів, № 9-10, с. 35-40.

40.Пахомов, Ю. М., Крымский С. Б., Павленко Ю. В. (1998) Пути и перепутья соврменной изивилизации. Київ, Международный деловой центр, 432 с.

41. Пекар, Валерій (2018), «Ситуація з економікою жахлива, все можуть змінити кілька простих речей», Універсум, Львів, № 5-6, с. 37-39.

42. Полулях, Іво (2012), «Економічна політика», Універсум, Львів, № 3-4, с. 28-30.

43. Райнерт, Ерік (2015), «Вільний ринок перетворить Україну на країну емігрантів», Універсум, Львів, № 11-12, с. 40.

44. Романчук, Олег (2011), «Роль науково-популярної літератури у пропаганді знань», Вісник Львівського університету, Сер. журн., Вип. 34, с. 188-194. 
45. Романюк, Михайло (1998), «Регулювання міграцій - вимога сьогодення», Універсум, Львів, № 7-8, с. 26-30.

46. Сікора, Веніамін (2001), «Україна: від капіталізму до капіталізму», Універсум, Львів, № 5-6, с. 15-19.

47. Сікора, Богдан (2002), «Російська економічна експансія в Україні», Універсум, Львів, № 7-8, 2002, с. 28-30.

48. Шевчук, Віктор (2012), «Газове питання: у пошуках справедливої ціни», Універсум, Львів, № 5-6, с. 21-24.

49. Шевчук, Володимир (1996), «Новітня парадигма економічних знань», Універсум, Львів, № 3-4, с. 42-44; № 7-8, с. 22-23.

50. Шпек, Роман (2018), «Транш МВФ - питання життя чи дефолту для України», Універсум, Львів, № 9-10, с. 37.

51. Шульман, Леонід (1999), «Чи вирветься Україна із зашморгу міжнародних фінансистів?», Універсум, Львів, № 5-6, с. 18-22.

52. Шульман, Леонід (1999), «Шлях деградації нації та держави - ліберально-монетаристське реформування економіки», Універсум, Львів, № 9-10, с. 27-31, 37-41.

53. Шульман, Леонід (2002), «Ринковий фундаменталізм», Універсум, Львів, № 11-12, c. $13-16$.

54. Шульман, Леонід (2005), «Ринковий фундаменталізм - загроза національній безпеці», Універсум, Львів, № 1-4, с. 14-22.

55. Яворський, Павло, Ніколаєва, Ольга, Шепотило, Олександр, Хорунжа, Марина, Таран, Світлана, Челмакіна, Крістіна (2019), «Як збільшити та диверсифікувати український експорт до Німеччини. Аналіз та рекомендації». URL: https://kse.ua/ wp-content/uploads/2019/09/KSE-Trade_Intesifying-UA-exports-to-Germany.pdf

\section{REFERENCES}

1. Argentyna - Valovoy vnutrenniy produkt. URL: https://knoema.ru/atlas/Aргентина/ BBП

2. Borshchevskyy, Serhiy (2007), «Liberalna model ekonomichnoho rozvytku Ukrayiny», Universum, Lviv, № 3-4, p. 5-10.

3. Borshchevskyy, Serhiy (2009), «Ukrayinska kryza: chy perezavantazhytsya "matrytsya"?», Universum, Lviv, № 1-2, p. 7-10.

4. Varych, Maryna (2014), Naukovo-populyarna zhurnalistyka yak metod komunikatsiyi u sotsiokulturnomu prostori», Obraz, Instytut zhurnalistyky KNU imeni Tarasa Shevchenka, vyp. 15, p. 5-13.

5. VVP Ukrainy - eto 25\% ot VVP Bavarii. URL: https://uainfo.org/blognews/1519984078vvp-ukrainy-eto-25-ot-vvp-bavarii.html

6. Vitlovkyy, Volodymyr (2015), «Deindustrializatsiya: natsionalne samohubstvo poukrayinsky», Universum, Lviv, № 3-4, p. 35-37; № 5-6, p. 24-26.

7. Vovkanych, S. (1999), Informatsiya, Intelekt, Natsiya, Lviv, Yevrosvit, $416 \mathrm{c}$.

8. Havrylyshyn B. (2009), Do efektyvnykh suspilstv: Dorohovkay v maybutnye: dop. Rymskomu Klubovi, Kyiv, Pulsary, 248 p.

9. Halchynskyy, A. S. (2013), Nooekonomika, Kyiv, Lybid, 472 p.

10. Halchynskyy, A. S. (1999), Ukrayina: postup u maybutnye, Kyiv, Osnovy, 220 p. 
11. Halchynskyy, A. S. (1996), Kinets totalitarnoho sotsializmu. Shcho dali?, Kyiv, Ukrayinski propileyi, $160 \mathrm{p}$.

12. Halchynskyy, A. S. (2011), Liberalizm. Uroky dlya Ukrayiny, Kyiv, Lybid', 288 p.

13. Halchynskyy, A. S. (2009), Kryza i tsykly svitovoho rozvytku, Kyiv, ADEF-Ukrayina, $392 \mathrm{p}$.

14. Hryhorchuk, Dmytro (1995), «Kredytni kooperatyvy - do dobra i krasy», Universum, Lviv, № 9-10, p. 24-26.

15. Dolishniy, Maryan (1994), «Na pra..., na li..., kruhom!», Universum, № 7-8, p. 28-29.

16. Zhuk, Yuriy (2004), «Ukrayina: chas vtrachenykh mozhlyvistey», Universum, Lviv, № 7-9, p. 5-8.

17. Zdorovyk, Vasyl (2008), «Inflyatsiya v Ukrayini», Universum, Lviv, № 3-4, p. 16-19.

18. Zdorovyk, Vasyl (2009), «Finansovo-ekonomichna kryza: yiyi prychyny ta naslidky», Universum, Lviv, № 1-2, p. 5-6.

19. Zlupko, S. M. (2000), Ekonomichna dumka Ukrayiny, Lviv, Lvivskyy natsionalnyy un-t im. Ivana Franka, 495 p.

20.Zlupko, S. M. uklad. (1998), Ukrayinska ekonomichna dumka: khrestomatiya, (1998), Kyiv, Znannya, 447 p.

21. Zlupko, Stepan (1994), «Ekonomika Ukrayiny: mynule, suchasne i maybutnye», Universum, Lviv, № 7-8, p. 27.

22.Zlupko, Stepan (1995), «Mynule, suchasne i maybutnye ukrayinskoyi ekonomiky», Universum, Lviv, № 11-12, p. 17-19.

23. Kysilyova, Tetyana (1997), «Komu vyhidna doroha z odnostoronnim rukhom?», Universum, Lviv, № 9-10, p. 14-15.

24. «Koruptsiya na mytnytsi zavdaye Ukrayini zbytkiv yu 5 milyardiv dolariv na rik» (2018). URL: https://www.dw.com/uk/sz-корупція-на-митниці-завдає-україні-збитків-у-5-мільярдів-доларів-на-рік/а-44963028

25. Kravchuk, Leonid (2000), «Pohlyad y XXI stolittya», Universum, Lviv, № 7-10, p. 6-11.

26. Kuzmenko, Volodymyr i Romanchuk, Oleh (1994) «U poloni Nadmonopoliyi», Universum, Lviv, № 1-2, p. 14-15.

27. Lanovyy, Volodymyr (2015), «Ekonomika bezhluzdoyi viyny», Universum, Lviv, № 7-8, p. 31-34.

28. Melnyk, Lidiya (2003), «Mozhlyvosti dlya ukrayinskykh pidpryyemstv pislya vstupu do SOT ta stvorennya zony vilnoyi torhivli z YS», Universum, Lviv, № 11-12, p. 25-27.

29. Mykhasyuk, Ivan (1996), «Ekonomichna polityka Ukrayiny», Universum, Lviv, № 7-8, p. 24-26.

30. Pavlovskyy, Mykhaylo (2001), «Vilnyy rynok bez derzhavnoho vtruchannya v ekonomiku - tse shlyakh do ekonomichnoho ta politychnoho krakhu derzhavy ta natsiyi», Universum, Lviv, № 11, p. 31. URL: http://www.universum.lviv.ua/magazines/universum/2001/5/pavl.html

31. Pavlovskyy, M. (1996), Shlyakh Ukrayiny: Shlyakh vlivo, shlyakh vpravo - khybnyy shlyakh, Kyiv, Tekhnika, $152 \mathrm{p}$.

32. Pavlovskyy, M. (1998), Ideolohiya prohresyvnykh reform dlya Ukrayiny, Kyiv, Tekhnika, $56 \mathrm{p}$.

33. Pavlovskyy, М. (1999), Наш вибір. Відродження чи руйнація, Київ,Техніка, 48 р.

34. Pavlovskyy, M. (1997), Suspilstvo ta ekonomika perekhidnoho periodu, Kyiv, Tekhnika, $152 \mathrm{p}$. 
35. Pavlovskyy, M. (2001), Stratehiya rozvytku suspilstva: Ukrayina i svit (ekonomika, politolohiya, sotsiolohiya), Kyiv, Tekhnika, $312 \mathrm{p}$.

36. Pavlovskyy, Mykhaylo (2000), «Svit i Ukrayina na porozi tertyoho tysyacholittya: shlyakhy rozvytku», Universum, Lviv, № 1-2, p. 12-15.

37. Pavlovskyy, Mykhaylo (2001), «Stiykist’ ekonomichnoyi systemy - neobkhidna umova zrostannya dobrobutu», Universum, Lviv, № 1-2, p. 11-16.

38. Pavlovskyy, Mykhaylo (2001), «Vilnyy rynok bez derzhavnoho vtruchannya v ekonomiku - shlyakh do ekonomichnoho i politychnoho krakhu derzhavy i natsiyi», Universum, Lviv, № 11-12, p. 33.

39. Pavlovskyy, Mykhaylo i Holovenko, Bohdan (2002), «Hlobalizatsiya i natsionalna stratehiya Ukrayiny u XXI stolitti», Universum, Lviv, № 9-10, p. 35-40.

40. Pakhomov, J. M., Krymskyy S. B., Pavlenko J. W. (1998) Puti i pereputya sovremennoy tsyvilizatsii. Kyiv, Mezhdunarodnyy delovoy tsentr, $432 \mathrm{p}$.

41. Pekar, Valeriy (2018), «Sytuatsiya z ekonomikoyu zhakhlyva, vse mozhut' zminyty kilka prostykh rechey», Universum, Lviv, № 5-6, p. 37-39.

42. Polulyakh, Ivo (2012), «Ekonomichna polityka», Universum, Lviv, № 3-4, p. 28-30.

43. Raynert, Erik (2015), «Vilnyy rynok peretvoryt' Ukrayinu na krayinu emihrantiv», Universum, Lviv, № 11-12, p. 40.

44. Romanyuk, O (2011), "Role of Popular Scientific Literature in the Promotion of Knowledge", Visnyk Lviv Univ., Ser. Journ., Is. 34, p. 188-194.

45. Romanyuk, Mykhaylo (1998), «Rehulyuvannya mihratsiy - vymoha syohodennya», Universum, Lviv, № 7-8, p. 26-30.

46. Sikora, Veniamin (2001), «Ukrayina: vid kapitalizmu do kapitalizmu», Universum, Lviv, № 5-6, p. 15-19.

47. Sikora, Bohdan (2002), «Rosiyska ekonomichna ekspansiya v Ukrayini», Universum, Lviv, № 7-8, 2002, p. 28-30.

48. Shevchuk, Viktor (2012), «Hazove pytannya: u poshukakh spravedlyvoyi tsiny», Universum, Lviv, № 5-6, p. 21-24.

49. Shevchuk, Volodymyr (1996), «Novitnya paradyhma ekonomichnykh znan'», Universum, Lviv, № 3-4, p. 42-44; №7-8, p. 22-23.

50. Shpek, Roman (2018), «Transh MVF - pytannya zhyttya chy defoltu dlya Ukrayiny», Universum, Lviv, № 9-10, p. 37.

51. Shulman, Leonid (1999), «Chy vyrvetsya Ukrayina iz zashmorhu mizhnarodnykh finansystiv?», Universum, Lviv, № 5-6, p. 18-22.

52. Shulman, Leonid (1999), «Shlyakh dehradatsiyi natsiyi ta derzhavy - liberalnomonetarystske reformuvannya ekonomiky», Universum, Lviv, № 9-10, p. 27-31, 37-41.

53. Shulman, Leonid (2002), «Rynkovyy fundamentalizm», Universum, Lviv, № 11-12, p. 13-16.

54. Shulman, Leonid (2005), «Rynkovyy fundamentalizm - zahroza natsionlaniy bezpetsi», Universum, Lviv, № 1-4, p. 14-22.

55. Yavorskyy, Pavlo, Nikolayeva, Olha, Shepotylo, Oleksandr, Khorunzha, Maryna, Taran, Svitlana, Chelmakina, Kristina (2019), «Yak zbilshyty ta dyversyfikuvaty ukrayinskyy eksport do Nimechchyny. Analiz ta rekomendatsiyi». URL: https://kse.ua/wp-content/ uploads/2019/09/KSE-Trade_Intesifying-UA-exports-to-Germany.pdf 


\title{
ECONOMIC PROBLEMS IN THE CIRCUMSTANCES OF THE UKRAINIAN STATE-BUILDING ON THE PAGES OF THE MAGAZINE «UNIVERSUM» (1993-2018)
}

\author{
Viktoriya Romanchuk \\ The all-Ukrainian Journal of Political Science, Futurology, Economics, \\ Science and Culture «Universum», \\ Box 2994, 79017, Lviv, Ukraine \\ e-mail: viktoriya.romanchuk7@gmail.com \\ https://orcid.org/0000-0003-1594-3995
}

In the article there are analyzed publications on the economic thematics in the magazine «Universum» during the years 1993-2018 that reflect the many-sided and controversial picture of the market reforms in the Ukrainian State. The authors of the magazine arise and discuss economic problems in the Ukrainian State what enables a better understanding of the reasons of the very slow and not always satisfactory process of the reform of the society on the basis of the market economics.

The main reason of the collapse of the economics of the Ukrainian State in the 90-ies of the past century was a very powerful and heavy integration of the economics of the Ukrainian SSR in the Soviet economic system. Remaining in the totalitarian system for a long time Ukraine was isolated from the international market. The profitability from the production in the USSR was based on three whales: cheap raw, cheap workforce, tight security of the internal market by the State monopoly on the external foreign trade. During the years of the so called ««reforms» Ukraine lost over $75 \%$ of its economic potential what is more than twice as much in comparison with the losses during the Second World War (40\%).

In 1991 Ukraine had the best possibilities among the other former Soviet republics of the USSR for the way out of the economic crisis. However, it was not possible to realize that because of the tax system - one of the worst in the whole world; because of the very high level of the corruption; because of the lack of trust in the society; because of the incomprehension of the national priorities; because of the shadow economy; because of the lack of the national strategy of the development; because of the permanent decrease of the fraction of the high-tech production in the structure of the GDP; because of the very big internal and external debt; because of the incomprehension of the fact that economics is a part of culture; because of the imperfect personnel policy of the State; because of the absence of the national patriotic lead when the politicians on the highest levels of power tolerate other states completely unhidden.

The publications in the «Universum» magazine on economic thematics confirm a longstanding classic experience: the basis of social relationships in the society is a distribution of the social work products. The society that wants to build its life on the basis of democratic principles needs the economic knowledge very much. There is a need of confidence that on a public basis there will be better perspectives for life and development to meet social needs.

It should be noted that the economic thematics is almost absent in the Ukrainian popular periodical press. In view of this state of affairs (a noticeable lack of content of the popular science on economic thematics) the editorial board of the «Universum» magazine devoted much of its publication to the promotion of the economic knowledge and the explanation of the causes and origins of economic problems of the modern Ukraine. The authors of the magazine 
combined in theirs publications the popularity of presentation with the professional analysis between the Ukrainian and world economics.

In the publications of the magazine there was paid attention to the problems of the free market; to the serious obstacles to development of the country because of the reduction of its labor potential; to the numerous negative consequences of Russia's economic expansion in various branches of the Ukrainian industry, in particular in the metallurgical, oil and gaseous branches what in the result enables not only to control the work of enterprises of Ukraine but also to influence the political, economical, public and information spheres; to the threats to the national security as a result of the capture by the Russian capital of the Ukrainian media market; to the obstacles for the investment climate of Ukraine due to its non-adherence to the economic sanctions of the western countries against the aggressor in the conditions of the open hybrid war of Russia against our State; to the urgent need for cheap capital for Ukraine to rebuild its industry etc.

The thoughts of the authors of the «Universum» magazine tend to focus on the future. In their articles they pointed to the ways to improve the State, raised issues of construction of the effective structure of the governing the country in all the areas of economy, noting the fact that the future of our State lies in the new technologies, in the highly profitable agricultural and industrial complex because for Ukraine the high quality products are very important.

On the complexity of economic issues, by the level of reasoning the publications of the «Universum» magazine are not inferior to the professional publications but at the same time these texts are popular and accessible for a wide range of readers.

Key words: economics, capital, Ukrainian statehood, market fundamentalism, market reforms, globalization, Russian expansion, popular science literature. 